\title{
Conjunctival Angioimmunoblastic T-Cell Lymphoma
}

\author{
Darshak S. Patel $^{a} \quad$ Paul Rundle $^{a} \quad$ Sachin M. Salvi ${ }^{a} \quad$ Malee Fernando $^{b}$ \\ Hardeep Singh Mudharc \\ a Sheffield Ocular Oncology Centre, Department of Ophthalmology, ${ }^{\text {b Department }}$ \\ of Histopathology, and 'National Specialist Ophthalmic Pathology Service (NSOPS), \\ Department of Histopathology, Royal Hallamshire Hospital, Sheffield, UK
}

\section{Key Words}

Angioimmunoblastic T-cell lymphoma - Conjunctiva - Epstein-Barr virus · Nodular episcleritis . Differential diagnosis

\begin{abstract}
Angioimmunoblastic T-cell lymphoma (AITL) represents an uncommon variant of T-cell lymphomas and most often presents insidiously with systemic symptoms. This report constitutes the first documented case of conjunctival AITL, masquerading as nodular episcleritis, and describes both the clinical and pathological findings. Furthermore, conjunctival T-cell lymphoma in general remains a rare occurrence, and a survey of previously reported cases reveals a wide variation in clinical presentation. A high index of suspicion, thorough examination and conjunctival biopsy are essential to reaching the diagnosis of conjunctival lymphoma.
\end{abstract}

\section{Introduction}

Angioimmunoblastic T-cell lymphoma (AITL) is an aggressive T-cell lymphoma subtype, accounting for $2 \%$ of all non-Hodgkin's lymphomas and $15-20 \%$ of all peripheral T-cell lymphomas [1]. Patients present with generalised lymphadenopathy, hepatosplenomegaly and cutaneous rashes, and the bone marrow is often involved at an early phase of the disease [1]. The aetiology is uncertain, but interestingly, over $75 \%$ of cases contain Epstein-Barr virus (EBV) within reactive B cells that are found amongst the neoplastic T-cell population [1]. It is an aggressive lymphoma, and patients often die of infectious complications. Some cases can also be complicated by the development of an EBV-driven high-grade B-cell lymphoma [1]. 
Patel et al.: Conjunctival Angioimmunoblastic T-Cell Lymphoma

Histologically, the key feature that distinguishes AITL from other peripheral T-cell lymphomas is the proliferation of high endothelial venules and follicular dendritic cells [1]. Conjunctival T-cell lymphoma is rare and more commonly secondary to systemic lymphoma [1]. In this case report, we detail the clinical and histopathological features of the first case of systemic AITL, presenting in the conjunctiva. The subject has given prior informed consent for this paper.

\section{Case Description}

A 72-year-old Caucasian male attended eye casualty with a 4-week history of painless enlarging lesions on his right eye. On examination, he had two pink, discrete, non-tender, bulbar conjunctival masses on his right eye (fig. 1a, b). He was treated with prednisolone sodium phosphate drops $(0.5 \%)$ for 8 weeks for presumed nodular episcleritis, but failed to demonstrate clinical improvement. Re-evaluation of the case raised the suspicion of conjunctival lymphoma, so the patient was referred to the local ocular oncology centre.

Seven months prior to his eye symptoms, the patient had been investigated for lethargy and night sweats. He had cervical lymphadenopathy, and blood tests revealed atypical lymphocytes, elevated lactate dehydrogenase of $528 \mathrm{IU} / \mathrm{l}$ (normal range 140-280 IU/l), polyclonal hypergammaglobulinaemia and a negative virus screen. A neck, thorax, abdomen and pelvis CT revealed bilateral cervical, axillary and groin lymphadenopathy with mild splenomegaly (fig. 1c). A cervical lymph node core biopsy followed by cervical node excision biopsy showed identical histology. The lymph node excision biopsy showed a proliferation of high endothelial venules between which was a lymphoid infiltrate, effacing the lymph node architecture, comprising small- to medium-sized lymphocytes with scattered larger blast cells. These lymphoid cells were positive for CD3, CD4 and PD-1. Scattered CD20+, PD-1-negative, EBV-positive reactive B cells were seen in the background, and numerous CD21-positive follicular dendritic cells were identified. PCR detected T-cell receptor (TCR) rearrangements in the TCR gamma V-J region confirming T-cell monoclonal population. The constellation of high endothelial proliferation with a polymorphous T-cell infiltrate, prominent follicular dendritic cell proliferation with the presence of PD-1-positive T cells, EBV-positive reactive B cells and a T-cell clone all pointed to an unequivocal diagnosis of angioimmunoblastic T-cell lymphoma (AITL). Meanwhile, his symptoms spontaneously resolved with an interval CT scan demonstrating an absence of splenomegaly and regression of lymphadenopathy. His AITL was thought to be clinically indolent, and he was kept under observation only.

Given the AITL history, the nodules on the conjunctiva were thought to represent secondary AITL. Ultrasound biomicroscopy showed a uniform thickening of the conjunctiva (fig. 1d) without scleral invasion. Histology of an incisional biopsy of one of the conjunctival lesions showed a morphology consistent with a diagnosis of AITL. At low power, the conjunctival substantia propria was effaced by a diffuse mass (fig. 1e). This comprised high endothelial venule proliferation (fig. 1f, arrow), polymorphous lymphoid infiltration (fig. 1g) that was positive for CD3 (fig. 1h), CD4 (fig. 1i) and PD-1 (fig. 1j). Furthermore, scattered EBVpositive reactive $\mathrm{B}$ cells were present in the background (fig. 1k). The only difference between the lymph

Fig. 1. a Right eye showing two pink conjunctival nodules. b Higher-power image of a showing the superior conjunctival nodule. c CT scan showing submandibular and submental lymphadenopathy (arrows). d Ultrasound biomicroscopy showing uniform thickening of the conjunctiva without scleral invasion. e Conjunctival biopsy at low power showing effacement of the substantia propria by the infiltrate (arrow). HE. $\times 40$. $\mathbf{f}$ Higher-power image of e showing high endothelial venules (arrows) surrounded by lymphocytes. HE. $\times 200$. g Diffuse conjunctival infiltrate composed of atypical lymphocytes. HE. $\times 400$. h CD3 immunohistochemistry showing that the atypical lymphocytes are positive for CD3, indicating a T-cell phenotype. $\times 400$. i CD 4 immunohistochemistry. The lymphocytes are also positive for CD4, indicating a T-helper cell phenotype. $\times 400$. j PD-1 immunohistochemistry. A proportion of the lymphocytes are positive for PD-1. $\times 400$. $\mathbf{k}$ EBV in situ hybridisation. Occasional brown, positive reactive B cells, in the background, harbouring EBV DNA. $\times 400$. I CD10 immunohistochemistry. A proportion of the T cells show aberrant expression of CD10, one of the hallmarks of AITL. $\times 400 . \mathbf{m}$ CD21 immunohistochemistry showing a dense meshwork of CD21-positive follicular dendritic cells within the original lymph node biopsy, a hallmark of AITL. $\times 400$.

(For figure see next page.) 
Ocular Oncology

and Pathology
Ocul Oncol Pathol 2015;1:71-76

DOI: $10.1159 / 000368247$

Patel et al.: Conjunctival Angioimmunoblastic T-Cell Lymphoma

node and conjunctival biopsy was CD10 expression by the lymphoma in the conjunctiva (fig. 11) and not in the lymph node, and the presence of prominent CD21 follicular dendritic cells in the lymph node (fig. $1 \mathrm{~m}$ ) but not in the conjunctiva. Both CD10 and CD21 are classically expressed on the T cells and follicular dendritic cell networks, respectively, in AITL [1].

The conjunctival biopsy confirmed secondary involvement by systemic AITL. The patient was referred back to haematology for consideration of chemotherapy, but 5 weeks following the biopsy, the eye lesions had spontaneously regressed and treatment was deferred.
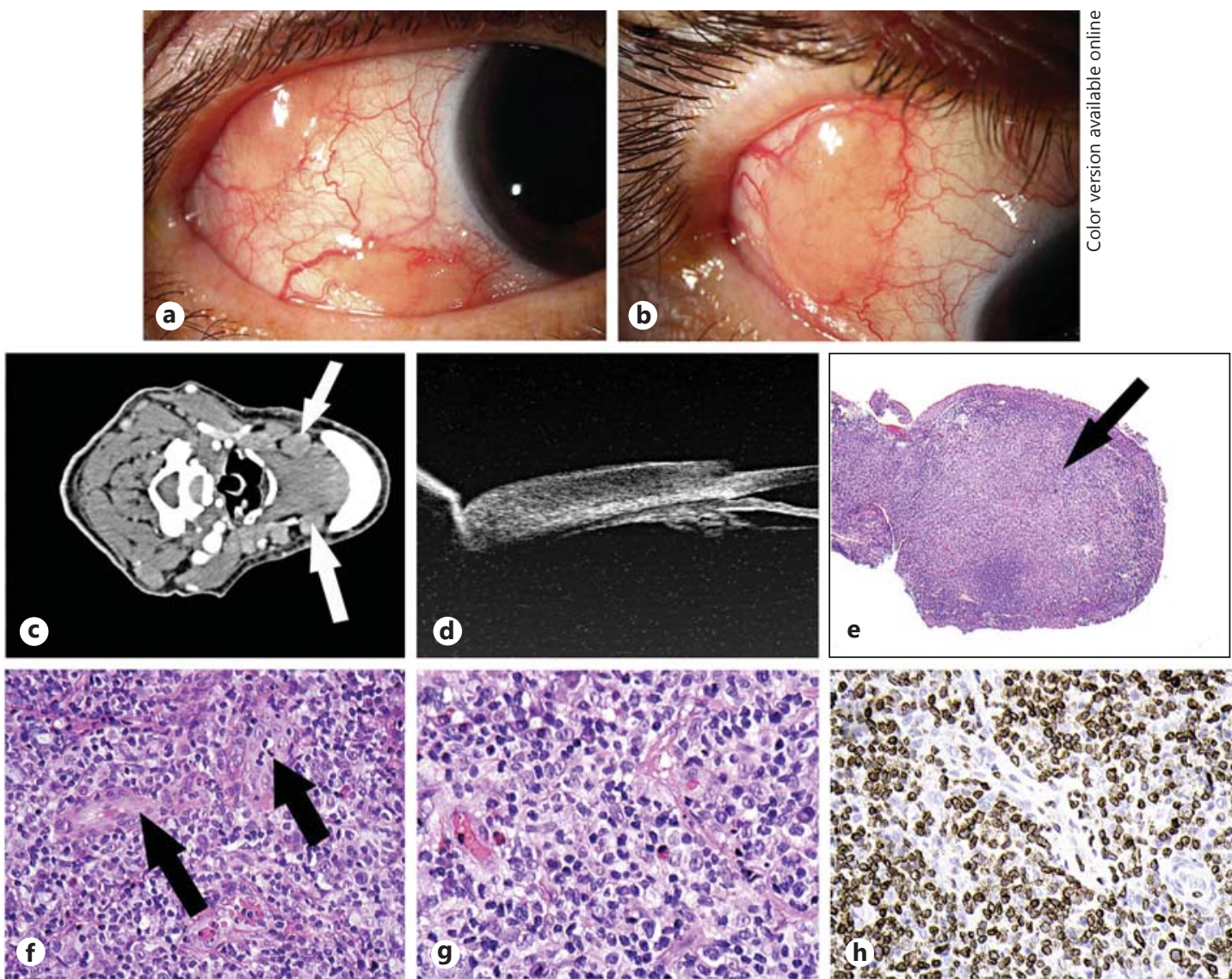

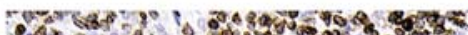
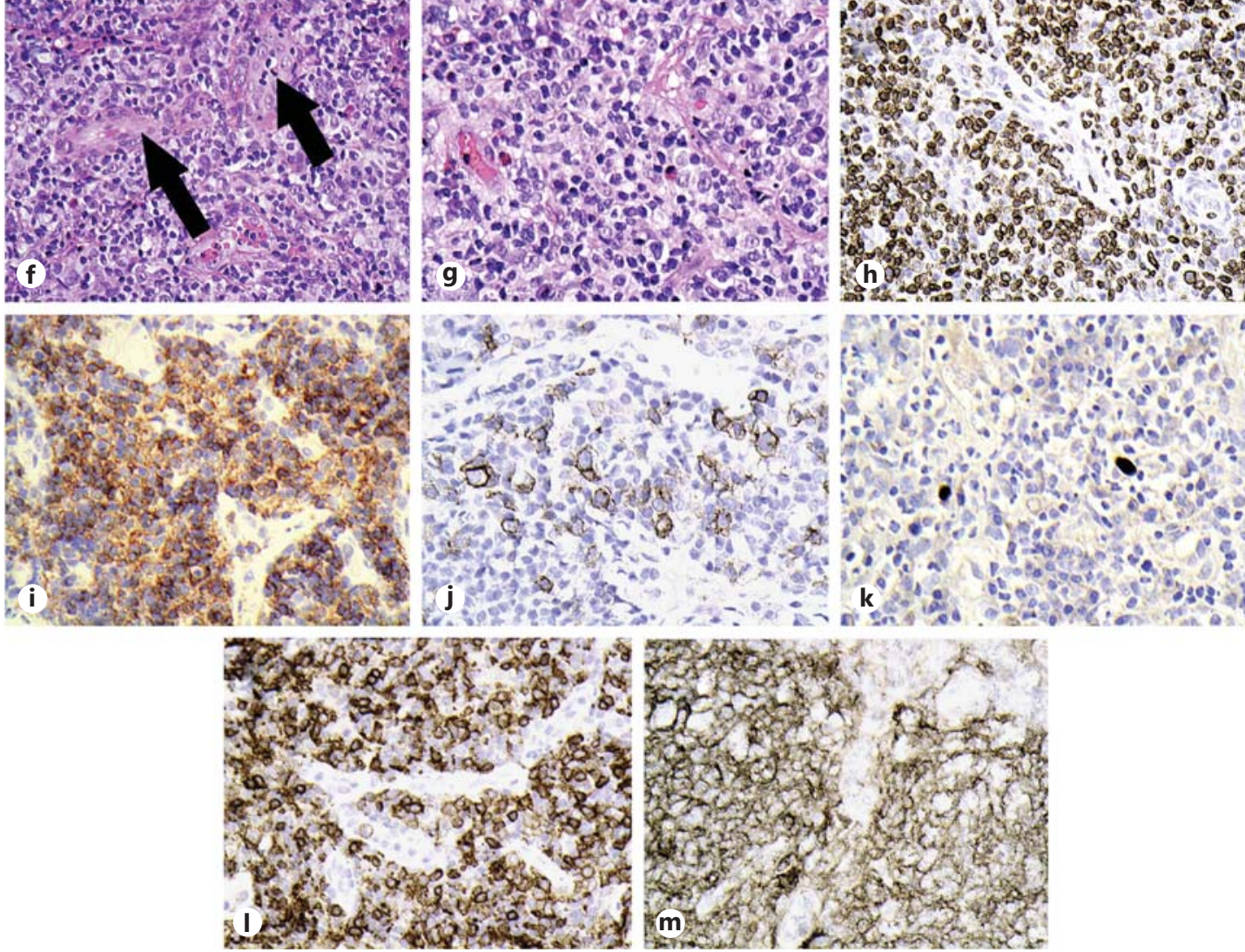
Table 1. Biopsy-proven conjunctival T-cell lymphoma cases

\begin{tabular}{|c|c|c|c|c|c|}
\hline Age & Gender & $\begin{array}{l}\text { Primary or secondary } \\
\text { conjunctival T-cell lymphoma }\end{array}$ & Presentation & Treatment and outcome & $\begin{array}{l}\text { First author } \\
\text { [Ref.], year }\end{array}$ \\
\hline 41 & M & $\begin{array}{l}\text { Primary natural killer/T-cell } \\
\text { lymphoma }\end{array}$ & $\begin{array}{l}\text { Tarsal conjunctival upper lid } \\
\text { swelling refractory to topical } \\
\text { steroids }\end{array}$ & $\begin{array}{l}\text { Systemic chemotherapy with regression } \\
\text { and relapse requiring combined } \\
\text { chemotherapy and radiotherapy, death } \\
\text { from bone marrow infiltration }\end{array}$ & $\begin{array}{l}\text { Widmer [6], } \\
2005\end{array}$ \\
\hline 57 & $\mathrm{~F}$ & Primary T-cell lymphoma & $\begin{array}{l}\text { Right elevated gelatinous, } \\
\text { bulbar lesion extending to the } \\
\text { limbus with injection }\end{array}$ & $\begin{array}{l}\text { Excision, cryotherapy and radiotherapy, } \\
\text { recurrence treated with topical } \\
\text { mitomycin, disease free at } 2 \text { years }\end{array}$ & $\begin{array}{l}\text { Al-Muammar } \\
{[7], 2006}\end{array}$ \\
\hline 59 & $\mathrm{~F}$ & Primary T-cell lymphoma & Right conjunctival lesion site & $\begin{array}{l}\text { Treated with topical chemotherapy, } \\
\text { disease free at } 3 \text { years }\end{array}$ & $\begin{array}{l}\text { Farmer [8], } \\
2006\end{array}$ \\
\hline 63 & $\mathrm{~F}$ & $\begin{array}{l}\text { Secondary diffuse large T-cell } \\
\text { lymphoma (primary right } \\
\text { maxillary sinus lymphoma) }\end{array}$ & $\begin{array}{l}\text { Bilateral episcleritis with } \\
\text { subsequent limbal thickening } \\
\text { and subepithelial infiltrates }\end{array}$ & $\begin{array}{l}\text { Systemic chemotherapy, in remission at } \\
1.5 \text { years }\end{array}$ & Hu [9], 1998 \\
\hline 76 & M & $\begin{array}{l}\text { Presumed secondary T-cell } \\
\text { lymphoma (no primary } \\
\text { found) }\end{array}$ & $\begin{array}{l}\text { Multiple subconjunctival bulbar } \\
\text { masses with symblepharon and } \\
\text { corneal pannus }\end{array}$ & $\begin{array}{l}\text { Excision and radiotherapy, disease free } \\
\text { at } 5 \text { years }\end{array}$ & $\begin{array}{l}\text { Coupland [10], } \\
1999\end{array}$ \\
\hline 29 & M & $\begin{array}{l}\text { Secondary HTLV-related } \\
\text { T-cell lymphoma (primary } \\
\text { cutaneous T-cell lymphoma) }\end{array}$ & $\begin{array}{l}\text { Bilateral limbal salmon-pink } \\
\text { conjunctival lesions with } \\
\text { injection }\end{array}$ & $\begin{array}{l}\text { Anti-Tac antibodies, recurrent } \\
\text { cutaneous and conjunctival lesions on } \\
\text { cessation of therapy }\end{array}$ & $\begin{array}{l}\text { Buggage [11], } \\
2001\end{array}$ \\
\hline 72 & $\mathrm{~F}$ & $\begin{array}{l}\text { Secondary (primary } \\
\text { nasopharyngeal T-cell } \\
\text { lymphoma) }\end{array}$ & $\begin{array}{l}\text { Left pink multinodular mass } \\
\text { involving the caruncle and } \\
\text { bulbar conjunctiva, enlarged } \\
\text { with topical steroids }\end{array}$ & $\begin{array}{l}\text { Systemic chemotherapy and } \\
\text { radiotherapy to the conjunctiva and } \\
\text { nasopharyngeal mass with regression } \\
\text { of the lesions, died } 11 \text { months later, } \\
\text { cause unknown }\end{array}$ & $\begin{array}{l}\text { Shields [12], } \\
2002\end{array}$ \\
\hline 16 & $\mathrm{~F}$ & $\begin{array}{l}\text { Presumed secondary large } \\
\text { anaplastic T-cell lymphoma }\end{array}$ & $\begin{array}{l}\text { Right superior fornix } \\
\text { salmon-pink patch }\end{array}$ & Death shortly after from septic shock & $\begin{array}{l}\text { Clarke [13], } \\
2003\end{array}$ \\
\hline 53 & $\mathrm{~F}$ & $\begin{array}{l}\text { Secondary (primary } \\
\text { oropharyngeal lymphoma) }\end{array}$ & $\begin{array}{l}\text { Right-eye painful scleritis, } \\
\text { anterior uveitis and elevated } \\
\text { intraocular pressure, refractory } \\
\text { to topical steroids and antivirals }\end{array}$ & $\begin{array}{l}\text { Systemic chemotherapy with partial } \\
\text { response, died whilst awaiting bone } \\
\text { marrow transplant }\end{array}$ & $\begin{array}{l}\text { Kirn [14], } \\
2007\end{array}$ \\
\hline 15 & M & $\begin{array}{l}\text { Secondary HTLV-associated } \\
\text { T-cell lymphoma }\end{array}$ & $\begin{array}{l}\text { Bilateral limbal keratitis and } \\
\text { follicles with injection }\end{array}$ & $\begin{array}{l}\text { Daclizumab with clinical improvement } \\
\text { in conjunctival lesions, later stopped } \\
\text { due to refractory systemic disease }\end{array}$ & $\begin{array}{l}\text { Larson [15], } \\
2012\end{array}$ \\
\hline 67 & M & $\begin{array}{l}\text { Secondary T-cell lymphoma } \\
\text { (primary sinus tumour with } \\
\text { pancreatic infiltration) }\end{array}$ & $\begin{array}{l}\text { Left painful bulbar and lower } \\
\text { fornix pink mass with corneal } \\
\text { ulceration and perilimbal } \\
\text { chemosis }\end{array}$ & $\begin{array}{l}\text { Systemic chemotherapy, oral steroids } \\
\text { and radiotherapy, death from } \\
\text { myocardial infarction }\end{array}$ & $\begin{array}{l}\text { Isola [16], } \\
2012\end{array}$ \\
\hline
\end{tabular}

Primary lymphoma cases are listed first in date order, followed by secondary cases. HTLV = Human T-cell lymphotrophic virus.

\section{Discussion}

Primary and secondary conjunctival T-cell lymphomas are rare [2]. Retrobulbar neuritis secondary to systemic AITL has been reported [3], but this case remains the first one of biopsy-proven conjunctival AITL (secondary).

The main clinical differential diagnoses in this case included conventional nodular episcleritis, paraneoplastic episcleritis and nodular scleritis. Nodular episcleritis presents with tender nodules to palpation with radial congested vessels running over them. Paraneoplastic episcleritis can occur as a phenomenon secondary to lymphoma without evidence of conjunctival secondaries [4]. However, in our case, the AITL nodules were painless and non- 
Patel et al.: Conjunctival Angioimmunoblastic T-Cell Lymphoma

tender, and the vessels appeared obscured on the surface. Nodular scleritis is more painful than nodular episcleritis and associated with scleral oedema and systemic autoimmune conditions, features not seen in this case. Furthermore the presence of identical T-cell clones on PCR in different locations at different times strongly favoured lymphoma.

A literature review of biopsy-proven conjunctival T-cell lymphoma revealed 11 documented cases, which are summarised in table 1 . Eight of these cases presented with an amelanotic conjunctival elevation, the majority (5/8) of which were located in the bulbar or forniceal conjunctiva, in keeping with the location of conjunctival lymphoma in general [5]. Five of the eight cases showed limbal and/or corneal changes varying from limbal thickening to frank keratitis and ulceration.

The main histological differential diagnosis from which AITL must be distinguished is angioimmunoblastic lymphadenopathy with dysproteinaemia (AILD) [1], which shares considerable clinical and morphological features with AITL. Like AITL, it can present with lymphadenopathy, skin rashes, organomegaly and raised lactate dehydrogenase levels [1]. Histologically, AILD shows high endothelial venular proliferation with effacement of the lymph node architecture, an infiltrate of T cells similar to AITL, and also a prominent population of follicular dendritic cell networks [1]. However AILD does not show an aberrant expression of PD-1 or CD10, and most importantly does not display clonal T-cell receptor rearrangement, which is present in AITL [1].

Spontaneous regression of systemic AITL without therapy is very rare, although it has been documented in a handful of publications [17-19]. Whilst this phenomenon is poorly understood, Schlegelberger et al. [19] showed that the presence of an extra third chromosome predicted a higher rate of spontaneous regression. We did not examine our case for this particular genetic change.

Our case highlights that new-onset conjunctival lesions mimicking nodular episcleritis in these patients may represent a recurrence of AITL. This should trigger a prompt conjunctival biopsy with expedited haematological review. Furthermore, a high index of suspicion should be maintained when dealing with cases of steroid refractory conjunctival nodules, and a thorough systems review and examination of adjacent structures such as the cornea may allude to a diagnosis of lymphoma.

\section{Disclosure Statement}

The authors declare that there are no conflicts of interest.

\section{References}

1 Swerdlow SH, Campo E, Harris NL, et al: WHO Classification of Tumours of Haematopoietic and Lymphoid Tissues, ed 4. Lyon, IARC Press, 2008.

-2 Al-Muammar A, Hodge WG, Farmer J: Conjunctival T-cell lymphoma: a clinicopathologic case report. Ophthalmology 2006;113:459-461.

3 Matthews JH, Smith NA, Foroni L: A case of angioimmunoblastic lymphadenopathy associated with a long spontaneous remission, retrobulbar neuritis, a clonal rearrangement of the T-cell receptor gamma chain gene and an unusual marrow infiltration. Eur J Haematol 1988;41:295-301.

-4 Thakker MM, Perez VL, Moulin A, Cremers SL, Foster CS: Multifocal nodular episcleritis and scleritis with undiagnosed Hodgkin's lymphoma. Ophthalmology 2003;110:1057-1060.

5 Shields CL, Shields JA, Carvalho C, Rundle P, Smith AF: Conjunctival lymphoid tumors: clinical analysis of 117 cases and relationship to systemic lymphoma. Ophthalmology 2001;108:979-984.

-6 Widmer S, Tinguely M, Egli F, Thiel MA: Lethal Epstein-Barr virus associated NK/T-cell lymphoma with primary manifestation in the conjunctiva. Klin Monbl Augenheilkd 2005;222:255-257.

7 Al-Muammar A, Hodge WG, Farmer J: Conjunctival T-cell lymphoma: a clinicopathologic case report. Ophthalmology 2006;113:459-461. 
8 Farmer JP, Lamba M, Merkur AB, et al: Characterization of lymphoproliferative lesions of the conjunctiva: immunohistochemical and molecular genetic studies. Can J Ophthalmol 2006;41:753-760.

-9 Hu FR, Lin JC, Chiang IP, Yeh KH: T-cell malignant lymphoma with conjunctival involvement. Am J Ophthalmol 1998;125:717-719.

10 Coupland SE, Foss HD, Assaf C, et al: T-cell and T/natural killer-cell lymphomas involving ocular and ocular adnexal tissues: a clinicopathologic, immunohistochemical, and molecular study of seven cases. Ophthalmology 1999;106:2109-2120.

11 Buggage RR, Smith JA, Shen D, Chan CC: Conjunctival T-cell lymphoma caused by human T-cell lymphotrophic virus infection. Am J Ophthalmol 2001;131:381-383.

12 Shields CL, Shields JA, Eagle RC: Clinicopathologic reports, case reports, and small case series: rapidly progressive T-cell lymphoma of the conjunctiva. Arch Ophthalmol 2002;120:508-509.

-13 Clarke B, Legodi E, Chrystal V, Govender D: Systemic anaplastic large cell lymphoma presenting with conjunctival involvement. Arch Ophthalmol 2003;121:568-570.

14 Kirn TJ, Levy NB, Gosselin JJ, Rosen WJ, Zegans ME: Peripheral T-cell lymphoma presenting as sclerouveitis. Cornea 2007;26:1147-1149.

15 Larson TA, Hu M, Janik JE, Nussenblatt RB, Morris JC, Sen HN: Interleukin-2 receptor targeted therapy of ocular disease of HTLV-1-associated adult T-cell leukemia. Ocul Immunol Inflamm 2012;20:312-314.

16 Isola V, Mazzacane D, Defelice N, et al: Malignant conjunctival T cell lymphoma diagnosed by punch biopsy as a primary manifestation of systemic cancer. Clin Ophthalmol 2012;6:777-780.

-17 Pangalis GA, Moran EM, Nathwani BN, Zelman RJ, Kim H, Rappaport H: Angioimmunoblastic lymphadenopathy. Long-term follow-up study. Cancer 1983;52:318-321.

18 Tobinai K, Minato K, Ohtsu T, Mukai K, Kagami Y, Miwa M, Watanabe S, Shimoyama M: Clinicopathologic, immunophenotypic, and immunogenotypic analyses of immunoblastic lymphadenopathy-like T-cell lymphoma. Blood 1988;72:1000-1006.

19 Schlegelberger B, Zwingers T, Hohenadel K, Henne-Bruns D, Schmitz N, Haferlach T, Tirier C, Bartels H, Sonnen R, Kuse R: Significance of cytogenetic findings for the clinical outcome in patients with T-cell lymphoma of angioimmunoblastic lymphadenopathy type. J Clin Oncol 1996;14:593-599. 